\title{
Methyltransferase Gene
}

National Cancer Institute

\section{Source}

National Cancer Institute. Methyltransferase Gene. NCI Thesaurus. Code C26110.

Methyltransferase Genes encode Methyltransferases, a subclass of transferase class

enzymes that catalyze the transfer of a methyl group from one compound to another.

$(\mathrm{NCl})$ 